\title{
A PICTORIAL OVERVIEW OF CALIFORNIA RIPARIAN SYSTEM CHARACTERISTICS
}

California riparian systems exhibit, in both structure and function, a mixture of regional uniqueness and global universality. An understanding of the nature and consequences of these characteristics can be very useful in interpreting observed field conditions and in designing and implementing management programs. Many of these characteristics are best described using on-site photography. The adage "one picture is worth a thousand words," is especially true here, where the diversity of species, topography, biogeography, climate, and geology found in California is so great. The set of photographs described below was selected to demonstrate and to assist in interpreting some of the more pervasive elements of structure and function in riparian systems both in California and elsewhere.

Frontispiece.--Valley oak (Quercus lobata) forest on the lower floodplain of the Cosumnes River, San Joaquin County. The wild grape (Vitis californica) draping the branches in areas exposed to the sun gives this magnificent forest a cathedral-1ike aspect. (Photograph 1983 by R.E. Warner.)

Page 1.--A stand of black cottonwood (Populus trichocarpa) at about 4,000 ft. elevation along the Yuba River, Nevada County. This species is replaced at lower, drier, and warmer elevations by Fremont cottonwood ( $\underline{P}$. fremontii), and at higher elevations by the quaking aspen ( $\mathrm{P}$. tremuloides). (Photograph $\overline{0} 19 \overline{83}$ by R.E. Warner.)

Page 45.--A stand of black willow (Salix gooddingii var. variabilis) along the American River Parkway, Sacramento. Willows vary greatly in form, depending upon species. Some are small, prostrate shrubs; others robust shrubs and small trees; and others, like that illustrated here, are capable of developing into a dense forest, $50 \mathrm{ft}$. or more in height. (Photograph $\odot 1983$ by R.E. Warner.)

Page 109.--The California sycamore (Platanus racemosa), here growing on the floodplain of the Sacramento River about 12 miles north of Sacramento, Yolo County. This species is strictly limited to streamside corridors and riverine floodplains, where it provides an attractive and ecologically valuable element to the riparian vegetation. Its tendency to produce cavities in trunks and major branches following limb loss makes it especially valuable to hole-nesting species of birds and mammals. (Photograph 01983 by R.E. Warner.)

Page 159.--Valley oak forest in Caswell State Park, San Joaquin County. This area has been protected from human-use damage for several decades and is one of the most intact and ecologically diverse riparian systems in California. Even here, however, recent studies have demonstrated that tree size/frequency ratios and other determinants of vegetation structure are unusual. Thus, while valley oak forests of Caswell State Park are among the most intact of California riparian systems, even they are not "primeval," further supporting the growing suspicion that because of ubiquitous, long-term, human use impacts, there are essentially no pristine riparian systems left in the state. (Photograph 01983 by R.E. Warner.)

Page 189.--A large specimen of the California buckeye (Aesculus californica) near the 100-year floodzone line on the Cosumnes River, Sacramento County. Less obligate a riparian species than the cottonwoods and willows, it is found concentrated in some riparian zones, especially riverine floodplain riparian systems, in the Central Valley. One finds, for example, a well-defined band of California buckeye in the lower floodplains of such rivers as the American, Cosumnes, Stanislaus, and Tuolumne. This band intermixes at its upper boundary with a broad band of valley oak and at its lower boundary with mixed cottonwood/0regon ash (Fraxinus latifolia) forest. During earlier, less disturbed times this California buckeye zone must have been even more pronounced, as some of the largest, most massive specimens of the species are still present where human-use impacts have been limited. The species is also concentrated along perennial and intermittent streams of the Coast Ranges, often well above the riparian zone, but where local circumstances produce shaded slopes and enhanced soil moisture conditions. (Photograph 01983 by R.E. Warner.)

Page 215.--Seeps are an inconspicuous but important type of riparian system, being essentially diminutive wet meadows. Studies of them have been neglected until recently. It is now becoming clear that they are often refugia for unique, riparian-dependent species of plants and animals. Like desert oases, seeps provide a special, insular biogeographical circumstance. This seep is located at about $1,520 \mathrm{ft}$. elevation near Placerville in E1 Dorado County. (Photograph by Cheryl Lemming Langley, with permission.) 
Page 241.--Along mountainous streams the banks and floodplains may be so steep, rocky, fractured, and/or unstable that the riparian zone is difficult to recognize. This segment of the upper Van Duzen River below Dinsmore (part of the state Wild and Scenic River System) illustrates this very well. Small pockets of riparian woodlands and meadows can be found where hydrologic and geologic circumstances permit. Other reaches may have only an occasional willow, alder, or other mesophyte growing amongst boulders and in the rocky, uneven streamside zone. (Photograph courtesy of Kerry J. Dawson, with permission.)

Page 287.--Yosemite Valley, Merced County, the floor of which contains grand and magnificent riparian systems. Carved from granite by glacial processes, the valley is a broad, nearly flat floodplain partially dammed by lateral and terminal moraines, where imported waters are delivered via a series of majestic waterfalls and cataracts. (Photograph 0 1983 by R.E. Warner.)

Page 383 (upper).--Wet meadows comprise a significant part of the Yosemite Valley riparian zone. High soil moisture levels from the imported water supplies provide the necessary water for mesic riparian plants, while at the same time excluding the more xeric upland species found on adjacent slopes and higher sites. (Photograph 1983 by R.E. Warner.)

Page 383 (lower).--Meadows constitute a major riparian resource wherever they occur, as the combination of high light intensity, soil moisture, nutrient availability, and amenability to fish and wildlife render them highly productive. They may be thought of as small riparian islands in the far less productive uplands. This meadow, at about $4,500 \mathrm{ft}$. elevation in the transition forest near Strawberry, Yuba County. Despite periodic meadow-hay cutting, grazing, and livestock yarding operations, it still retains much of its original structure and provides habitat for many wildlife species. (Photograph 1983 by R.E. Warner.)

Page 437 (upper).--Vernal pools are another type of seasonal wetland with a strong riparian component. Precipitation is captured during winter rains in these impermeable-bottomed lowlands, creating shallow seasonal pondlets or "pools." As spring arrives and the imported water evaporates, concentric bands of wildflowers and other vegetation develop along the riparian zones of the pools. Many of these plant species are especially adapted to vernal pool circumstances. This vernal pool in the Vina Plains Preserve of The Nature Conservancy is just beginning to dry out with the onset of spring. (Photograph by Hella Hammid and The Nature Conservancy, with permission.)

Page 437 (lower).--Greater and Lesser Sandhill Cranes rising from the riparian floodplain grasslands of the Mokelumne River. For some five million years Sandhill Cranes have been flying south each winter to use this riparian resource for foraging and roosting. Recently, however, a strong trend to convert the riverine bottomlands to vineyards and other land uses incompatible to the cranes has developed. These land-use practices are so damaging to the native Sandhill Cranes that whole regional crane populations could be decimated. (Photograph - 1983 by R.E. Warner.)

Page 481 (upper).--Saratoga Springs is a unique type of desert riparian system in the southern end of Death Valley National Monument. Its imported water source is a series of springs emerging from the base of some rocky hills to the right. The encompassing sand dune ridges are maintained by the interaction of wind and stabilizing shrubs and grasses. The inner riparian zone is lush and green, being protected from wind by the dune barrier. The area receives less than five inches precipitation per year. (Photograph 01983 by R.E. Warner.)

Page 481 (lower).--In this palm oasis the native riparian palm Washingtonia filifera finds adequate moisture in a surface-emergent aquifer on the desert floor of Anza-Borrego Desert State Park. In such riparian systems water may appear only very rarely--or not at all-at ground level, sometimes limiting the ability of riparian shrubs and groundcover species to survive. Digging at the base of these trees produced wet, sandy soil. During wet years water has been recorded at ground level. (Photograph 01983 by R.E. Warner.)

Page 537 (upper).--In the drier, warmer, more southerly portion of its range, the red alder (Alnus rubra) is closely associated with and dependent upon riparian systems, occurring as a streamside species. In this photograph of a stream in the Coast Ranges about five miles south of Point Reyes Station, the species can be seen as relatively riparian-dependent, the trees closely following the watercourse. (Photograph 01983 by R.E. Warner.) 
Page 537 (lower).--Further north, as climate tempers and precipitation increases, the species abandons its riparian dependency and is regularly found on moist, open slopes and along roadside berms. Here the species is growing vigorously in roadside gravels on coastal Vancouver Island, British Columbia. Precipitation in this region is between 100 and 200 inches per year. This varying dependency upon the riparian zone, resulting from changes in climatic circumstances, is seen in many riparian species. (Photograph 01983 by R.E. Warner.)

Page 577 (upper).--A mature grove of Fremont cottonwood on the floodplain of the South Fork Kern River, Kern County. One of the finest remaining cottonwood/willow riparian systems in southern California, the area has now been preserved by The Nature Conservancy, and efforts are underway to rehabilitate portions that have been most seriously affected by grazing, clearing for agriculture, and other human-use impacts. (Photograph 01983 by R.E. Warner.)

Page 577 (lower).--The floodplain riparian wetlands of the South Fork Kern River riparian system illustrate very well one of the major geologic principles in the formation and development of these unique systems. As can be seen here, there are large expanses of meadow as well as cottonwood/willow forest. The South Fork Kern River canyon was initially cut down several hundred feet below its present level, and at one time was a relatively steep-walled canyon. Subsequent downstream faulting and earth movement created a barrier across the watercourse. Today the canyon is filled with unconsolidated alluvial sediments and the resulting aquifer filled, raising water table height to at or near ground level. (Photograph 0 1983 by R.E. Warner.)

Page 633 (upper).--It is easy to see how riparian systems can be major contributors to ecological diversity and productivity in arid and semi-arid regions. Little Panoche Creek provides a ribbon of mesic sumer vegetation and shade through the otherwise arid, treeless uplands. This narrow band of riparian vegetation is heavily used by both wildlife and domestic livestock. (Photograph $\odot 1983$ by R.E. Warner.)

Page 633 (lower).--The world's second largest tree (the largest is found in similar circumstances), a coast redwood (Sequoia sempervirens), in the Rockefeller Grove of Redwood State Park, Humboldt County. This immense specimen is growing on the floodplain riparian zone of Bull Creek and is one of the largest living beings on the face of the earth. Note from the photograph that its dimensions are: tree circumference--53 ft.; diameter--17 ft.; and height $346.5 \mathrm{ft}$. (Photograph $\odot 1983$ by R.E. Warner.)

Page 687 (upper).--An example of a very important but poorly understood riparian phenomenon common in the Central Valley. This "lake" or "slough" is formed by runoff erosion in upland areas immediately above the floodplain. The lower ends of these lakes empty onto the floodplain itself, and are at times blocked off and isolated from the floodplain by silt plugs, beaver dams, and other barriers. These lakes are generally perennial and host large populations of waterfowl, wading birds, and other wildlife. When left undisturbed by man, they are often exquisitely beautiful. The site illustrated here is along the lower Cosumnes River, Sacramento County. No special effort has been made to preserve these sites, and they are rapidly being lost to overgrazing, drainage, and forest clearing. (Photograph $\odot 1983$ by R.E. Warner.)

Page 687 (lower).--As the lowest-lying area of the Central Valley floodplain is reached, the character of the watercourses changes. Rivers and streams become slower moving, and sloughs, oxbows, lakes, and other secondary waterways with warm, nutrient-rich waters become prominent. Shortly before its confluence with the Mokelumne River, the lower Cosumnes River, shown here, becomes a series of slow-moving, warm water, high nutrient waterways. Wildlife is abundant here at all seasons. Indeed, this zone appears to be one of the most productive in the entire Central Valley ecosystem. (Photograph 01983 by R.E. Warner.)

Page 721 (upper).--One of California's more remarkable watercourses, with its attenuated riparian zone. This small, perennial freshwater stream derives from springs and seeps in the mountains forming the western boundary of Death Valley in Death Valley National Monument. The water is fresh enough to support a population of the native (and endangered) species of pupfish, as it passes through the salt flats comprising the floor of Death Valley. (Photograph 0 1983 by R.E. Warner.)

Page 721 (lower).--A closer view of the riparian zone of the small stream illustrated above. The narrow, dark line at the edge of the crystalline salt concretions is the riparian zone, a growth zone for several species of algae. This riparian algal growth zone, and algal mats on the bottom of the streambed, are the two major sites of primary production for this peculiar stream ecosystem. (Photograph 01983 by R.E. Warner.) 
Page 747 (upper).--As a result of nearly two centuries of diverse, unplanned, and often destructive land-use practices, thousands of miles of smaller streams, creeks, and sloughs throughout California have been largely divested of their riparian resources. This is especial1y pronounced and observable in the San Joaquin Valley, where precipitation rate is low and the rate of natural recovery of riparian vegetation is slow. This small watercourse bordering Sandy Mush Road, San Joaquin County, formerly had a corridor woodland of Fremont cottonwood, willow, and riparian shrubs. Systems such as this have been variously grazed, burned, and cleared, until today little riparian vegetation remains. From an ecological point of view, the value of these systems is often reduced 90-95\%. (Photograph 01983 by R.E. Warner.)

Page 747 (lower).--Subsiding water tables are responsible for the loss of large areas of riparian vegetation. The willow-lined sloughs shown here are part of the formerly massive natural drainage system connecting the Kern River with Kern, Buena Vista, Goose, and Tulare lakes. Historically, overflow water moved via this system to the San Joaquin River for discharge to the Pacific Ocean. The terrestrial component of this extensive wetland system comprised a major riparian resource for that region and provided essential habitat for the endangered tule elk as well as many other species. Diversions for agricultural irrigation in the late $1800 \mathrm{~s}$, intensive groundwater pumping from agricultural wells in the early 1900s, and finally construction of Isabella Reservoir and further diversion of the Kern River water supplies removed so much water from the system that it dried up and its dependent riparian vegetation died. The photograph shows one of these dry sloughs in what is now the Tule Elk State Reserve. The trees are today but dead carcasses bordering the now-dry slough. (Photograph 01983 by R.E. Warner.)

Page 783 (upper).--Rock riprap on the western bank of the Sacramento River north of Sacramento. This controversial structural erosion control measure is aesthetically defacing, ecologically damaging, expensive, and subject to failure. Yet it is one of the few structural bank erosion protection devices that has proven relatively effective over the years. Over time, as alternate bank protection strategies--e.g., river meander zones, integrated pest control on levees, integrated floodplain management, riparian vegetation reestablishment-become available and are accepted at policy and administrative levels, use of rock riprap and other controversial structural erosion control will diminish. Until then, because one of the principal mandates upon the Corps of Engineers remains the protection of life and property from flood damage, riprapping will continue to be used despite its well known negative values. (Photograph 01983 by R.E. Warner.)

Page 783 (lower).--Rafting and other forms of boating recreation are developing into important uses of California's river systems. Here a group prepares to run the Merced River immediately below Yosemite National Park. Maintenance and restoration of riparian system values is very important to these user groups, as both the ecological and aesthetic values of the sport depend upon the health of the riparian zone. On such excursions, much time is spent picnicking, resting, and camping in the riparian zone. It is this type of recreational activity, in addition to recreational fishing, that feels most keenly the impact of structural bank protection measures such as riprapping. (Photograph O 1983 by R.E. Warner.)

Page 825 (upper).--Cattle foraging for food in the riparian zone of Little Panoche Creek. Note the absence of groundcover and shrubcover vegetation and presence of prominent browse lines on the Fremont cottonwood. Cattle are attracted to the riparian zone by the shade, (usually) high moisture, palatable vegetation, and (usually) free water. (Photograph 01983 by R.E. Warner.)

Page 825 (lower).--Human disturbance has caused the cattle to leave immediate area. Note complete absence of cottonwood regeneration even though adult plants are present. In due course the remaining, heavily browsed trees will die, and this reach of stream will become devoid of tree cover. This pattern of gradual decline of ecological diversity and quality through livestock-induced destruction of riparian vegetation is common throughout the arid and semi-arid regions of California. (Photograph 01983 by R.E. Warner.)

Page 867 (upper).--Many human-use riparian impacts are subtle and not readily apparent for many years. The effects of two different livestock management programs on adjacent reaches of the same watercourse are illustrated here. This photograph, looking west immediately upstream from the property line fence, shows a young, recovering riparian system with vigorous groundand shrubcover growth. This vegetation, while deriving from a previously more heavily degraded riparian system and hence in no way "pristine," none-the-less indicates the regeneration potentials for such small streams. (Photograph $\bullet 1983$ by R.E. Warner.) 
Page 867 (lower).--Looking downstream from the fenceline dividing the two properties, one sees denuded streambanks, remnant trees with browselines, and an almost complete absence of vegetation regeneration of any kind. This latter pattern of denudation from long-term overuse of the riparian zone is one of the more common riparian land-use patterns seen throughout California. (Photograph 01983 by R.E. Warner.)

Page 905 (upper).--Some symptoms of hydrologic and vegetative instability damaging to riparian values: 1) cut or eroded streambanks, where roots are showing and the bank faces are unstable; 2) lack of ground- and shrubcover vegetation (grasses will of ten remain throughout a sequence of severe erosion damage); 3) grossly uneven size classes of trees. Here only a few decadent cottonwoods, willows, and sycamores remain after decades of overuse. (Photograph 0 1983 by R.E. Warner.)

Page 905 (lower).--Some further symptoms of riparian erosion problems: 1) widening and shallowing of watercourse; 2 ) reduction in streamside vegetation cover, with reduced amounts of shade and increasing water temperatures; 3) significant numbers of dead and dying trees. Healthy streamside forests and woodlands have low rates of tree mortality, and tree carcasses are present but uncommon. Here dead mature willows are abundant; 4) lack of regeneration of dominant tree species; 5) loss of palatable mesic groundcover and shrubcover plants. (Photograph 01983 by R.E. Warner.)

Page 957 (upper).--A good, relatively non-destructive use of riparian zones where competing human use interests exist. This golfcourse near Galt, Sacramento County, makes use of the aesthetic values of the Dry Creek riparian zone, while retaining intact most of its ecologic and hydrologic values. Golf carts trundle across bridges, making both sides of the system accessible for recreational use. (Photograph 01983 by R.E. Warner.)

Page 957 (lower).--Some riparian systems are especially attractive and uniquely suited for dispersed recreation activities which, if properly designed, can protect and restore the systems while making them accessible for non-consumptive uses. Shown here is Orestimba Creek where it crosses Interstate 5 near Stockton. The floodplain supports a unique and beautiful stand of mature California sycamore. Unfortunately, the sycamore stand has been continuously grazed for several decades, the inevitable result being no sycamore or other riparian tree reproduction and loss of vegetative diversity and plant cover. If the present land-use practices prevail, the sycamore woodland will ultimately be destroyed. A park has been proposed for the site, which, if effectively implemented, could lead to long-term protection and recovery of the system. Presently the concept has low priority because the intrinsic riparian values and the potential symbiosis of park and natural system have not been fully factored into the planning process. (Photograph 01983 by R.E. Warner.) 
